\title{
The Use of Handheld Navigation Receivers GARMIN GPSmap62st for the Unambiguous Identification of the Cadastral Plots in the Field**
}

\section{Introduction}

The issue of the use of handheld GPS receivers in various fields has been the subject of many publications. Most of them concern the use of this device for land and naval navigation [1-3,9] in accordance with its primary function. In several publications some of the functions of handheld navigation receivers GARMIN GPS were tested in a variety of engineering tasks $[5,7,8,11,13]$. These publications also include the results of the mutual comparisons of the succeeding models in the producer series, compared in terms of both physical characteristics and the precision. The usefulness of such instruments in the field of surveying is limited due to the relatively low positioning accuracy, resulting from the fact that it is a navigation receiver for mainly tourist purposes. Certainly, the receiver is not suitable for use in tasks of engineering geodesy. According to Plewako [10]:

The accuracy of GPS handheld receivers can be regarded as the same as an error (determined with
their use) of the location of a geodetic point of a network of II or III class. Using this criterion, re-
peatedly, in different regions of the southern Poland and for different reference systems, the occur-
rence of a systematic factor of considerable size was discovered. Removing this factor from a set of
observations allows getting a reduction in the value of point location error. This error is at the level
of about $\pm 1.5 \mathrm{~m}$ for close to optimal measurement conditions. This accuracy drops to approximately
$\pm 3 \mathrm{~m}$ for the area, where there are not many obstacles in the way of signals from the satellite. When
the access to the signals is limited for example, by high buildings, dense forest, etc. the error increas-
es to $\pm 10 \mathrm{~m}$ and more. The access to the signals of EGNOS system satellites significantly improves
and adds credibility to the measurement results.

This accuracy is confirmed by further studies in [12].

In the studies $[5,7,8]$ has been shown the possibility of wider use of hand-held receivers than land or water navigation. In addition to the applications listed in the cited references widely known applications in Geocaching can be added.

* University of Agriculture in Krakow, Faculty of Environmental Engineering and Land Surveying, Department of Land Surveying, Krakow, Poland

** This work was carried out within the statutory studies of the University of Agriculture in Krakow, Faculty of Environmental Engineering and Land Surveying, Department of Land Surveying, no. DS/3356/KG/15 
As reported in [14]:

Geocaching is a treasure hunting game with the use of GPS. The leading idea is to find a container (called "geocache") previously hidden in the area and noting this fact on a special website. Geocaching is an international game addressed to the adventurers of all ages.

Investigated in this work GPSmap 62st receiver is also in the precision group of receivers used in this game. Its popularity in Geocaching indicates the effectiveness in the identification of objects in the field. It seems to be reasonable to undertake research in the use of it to find a large surface area in the form of plot.

So the subject of this study relates to the suitability of the handheld Garmin navigation receivers GPSmap62st for the unambiguous identification of the position in the field of cadastral plots, especially for the purpose of real estate appraisal.

\section{The Research Area}

The object of the study consisted of a complex of 52 cadastral plots with varying degrees of field details density. Figure 1 shows the extent of the elaboration on the background of orthophotomap. Figure 2 shows the cadastral parcels complex with numbers from the database EGiB.

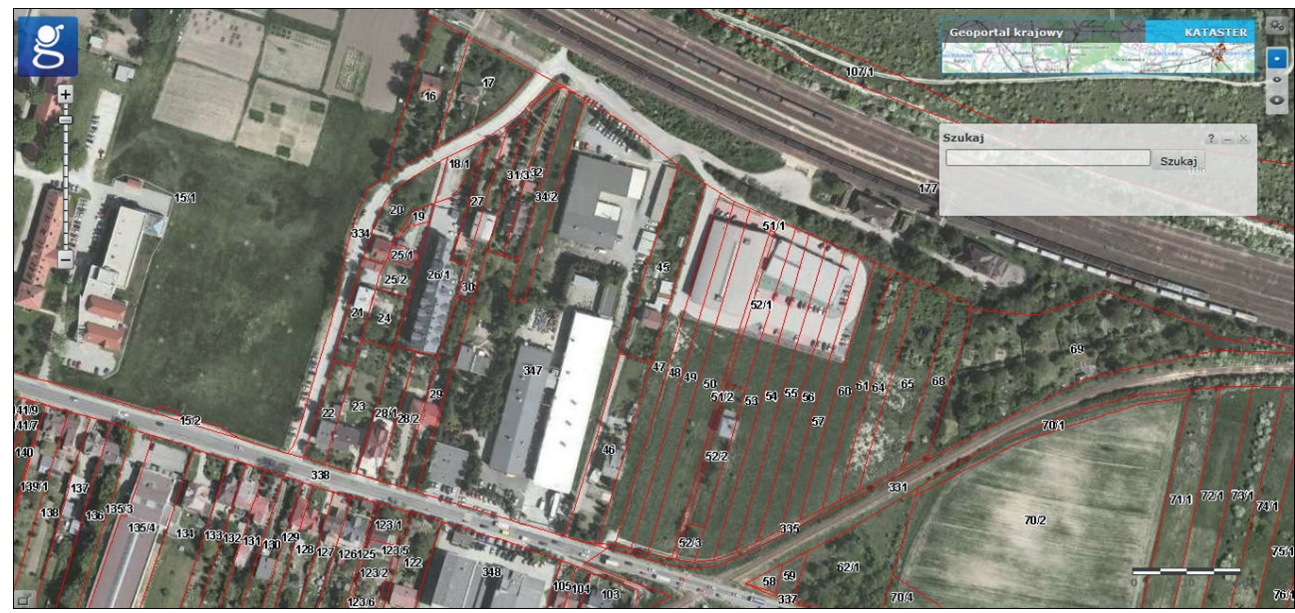

Fig. 1. Selections of research area based on data from Geoportal 2 (scale 1: 2000)

On the basis of Figures 1 and 2 various degrees of details density and significant tree coverage and development can be seen for the most part of the research area. Object of research is located near the Balicka street in Krakow in the neighborhood of low-rise family buildings and industrial buildings. Terrain relief is typical for this part of Małopolska. The area does not have a large height differences, and 
the horizon allows for observations with 6-10 GPS satellites. Before taking up the study field conditions were tested by the field research, and measuring equipment configured so as to produce maximally accurate positioning.

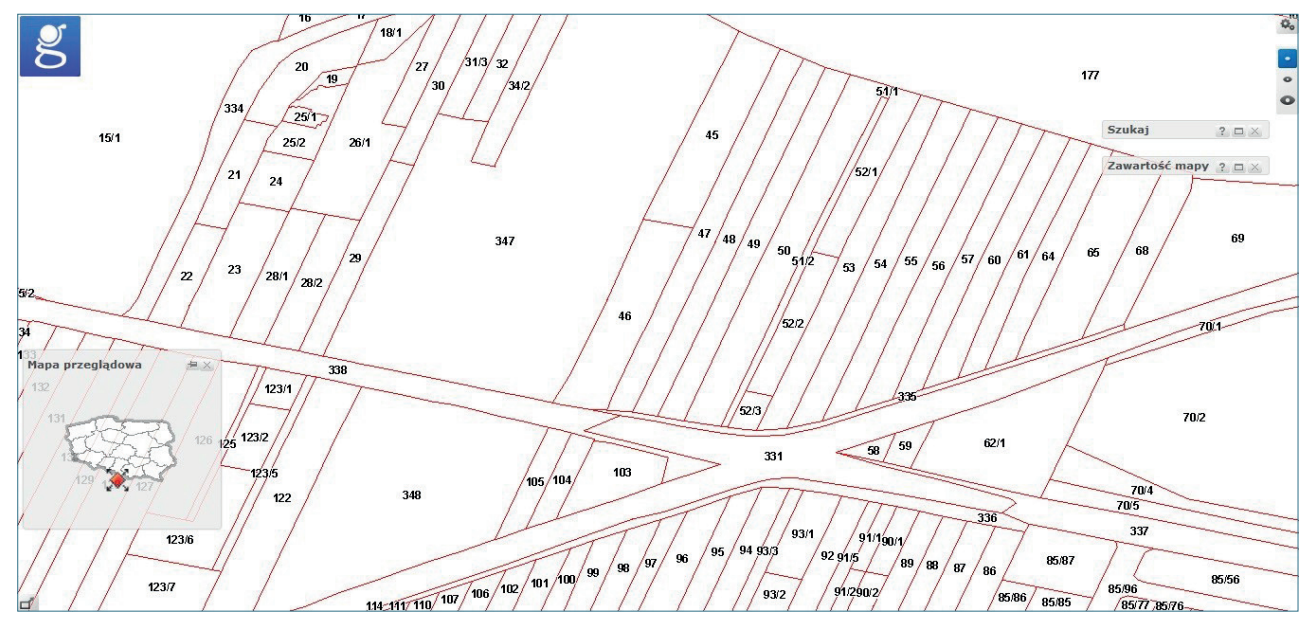

Fig. 2. Selections of research area based on data from Geoportal 2 (scale 1: 2000)

\section{Methodology}

Research was carried out in the spring to eliminate obscuring the horizon by tall trees growing in the area of research. In this way, at temperature in the range of $10^{\circ} \mathrm{C}$, moderate humidity and hours of weaker traffic on Balicka street, the optimal conditions for measurement with the used navigation receiver were provided. In order to obtain the best possible positioning accuracy in the receivers EGNOS correction was activated. In addition, the function AVERAGING POSITION and an external antenna were used.

The study consisted of two stages. In the first one data in the form of approximate coordinates $(\mathrm{N}, \mathrm{E})$ of the cursor inside the cadastral plot, have been read from the service Geoportal 2 and stored in a text file in the memory of the receiver GPSmap62st. The next step was field measurement consisting in the use of navigation functions of the receiver and navigation to the indicated points with coordinates (N, E). Positioning was performed under optimum measurement conditions, characteristic for the group of handheld receivers and was intended to achieve the indicated points and saving (N1, E1) in the WAYPOINT mode. The second stage consisted in registration in the GPSmap62st receiver's memory the actual coordinates of the points inside cadastral plots, based on field inquiry, and then re-performing the navigation to the indicated points to identify the position of the plot based on coordinates (N2, E2). 


\section{Results}

The results of the field and office works are compiled in the respective tables. In Table 1, among other things, are placed the results of the coordinates of cadastral parcels based on data from the Geoportal. In the same table there are the results of positioning for successive measurements of coordinates (N1, E1), (N2, E2) in the field. In the case of the data read from the Geoportal - in order to eliminate mistakes regarding the proper point of cursor insertion inside the plot - coordinates were read while maintaining a safe margin for distance from the borders of the plot. The measurement data were recorded using the most accurate position format " $\mathrm{dd} \mathrm{mm}$ ss.ss", where " $\mathrm{dd}^{\mathrm{d}}$ " denotes degrees, "mm" denotes minutes, and "ss.ss" denotes seconds with the accuracy of (0.01 s).

During the office works the coordinates were rounded to the nearest second, and then were transformed into the 1992. For this purpose WINKALK program was used. In this manner, the differences in terms of positioning, expressed in metric measure were obtained. They are shown in Table 2.

The resulting difference of coordinates, expressed in metric measure, is in the range $0-11 \mathrm{~m}$ (for $X$ coordinate) and 0-9.4 $\mathrm{m}$ (for $Y$ coordinate). The biggest differences showed the results of measurements of the location of the plot with the registration number 347 located in the center of the complex of analyzed plots. This is because, that on that plot, there are obstacles in the form of high-rise buildings (densely built) and trees.

\section{Recapitulation and Conclusions}

In some of the studies mentioned in references background maps from Geoportal were useful $[7,8]$. However, in these papers quite different possibilities of using handheld GPS receivers has been studied namely for the purposes of updating thematic maps (mainly tourist), as well as the identification of point objects in the field. This service also proved to be useful in this study. According to the information contained in the mentioned web address [15]:

[...] data contained in the service, concerning parcels originating from the LPIS (Land Parcel Identification System), are only approximate and are not within the meaning of regulations the data from the EGiB.

The present studies have shown, however, their great importance in the field of the use for the purpose of finding a surface object in the form of the cadastral plot. This particularly applies to those cases, when there is a need to find a plot in the area without the possibility of the use of its address data. For example, by a commonly used method, which consists in entering the address in the mobile phone application. 
Table 1. Coordinates of plots based on data from GEOPORTAL (N, E)

and of twofold measurements GPSmap62st N(1), E(1) and GPSmap62st N(2), E(2)

\begin{tabular}{|c|c|c|c|c|c|c|}
\hline $\begin{array}{c}\text { Number of } \\
\text { plot }\end{array}$ & $\begin{array}{c}\mathrm{N} \\
\text { Geoportal } \\
\text { [dd mm ss.ss] }\end{array}$ & $\begin{array}{c}\text { E } \\
\text { Geoportal } \\
\text { [dd mm ss.ss] }\end{array}$ & $\begin{array}{c}\mathrm{N}(1) \\
\text { GPSmap62st(1) } \\
\text { [dd mm ss.ss] }\end{array}$ & $\begin{array}{c}\mathrm{E}(1) \\
\text { GPSmap62st(1) } \\
\text { [dd mm ss.ss] }\end{array}$ & $\begin{array}{c}\mathrm{N}(2) \\
\text { GPSmap62st(2) } \\
\text { [dd mm ss.ss] }\end{array}$ & $\begin{array}{c}\mathrm{E}(2) \\
\text { GPSmap62st(2) } \\
\text { [dd mm ss.ss] }\end{array}$ \\
\hline $15 / 1$ & 500501.93 & 195113.78 & 500501.85 & 195113.66 & 500501.93 & 195113.78 \\
\hline 16 & 500502.51 & 195119.71 & 500502.43 & 195119.77 & 500502.51 & 195119.71 \\
\hline 17 & 500502.75 & 195121.28 & 500502.38 & 195121.43 & 500502.75 & 195121.28 \\
\hline 334 & 500500.01 & 195117.34 & 500559.15 & 195117.22 & 500500.01 & 195117.34 \\
\hline 20 & 500500.28 & 195118.37 & 500500.45 & 195118.23 & 500500.28 & 195118.37 \\
\hline 21 & 500458.50 & 195117.34 & 500458.26 & 195117.32 & 500458.50 & 195117.34 \\
\hline 22 & 500456.65 & 195116.42 & 500456.33 & 195116.41 & 500456.65 & 195116.42 \\
\hline 23 & 500456.72 & 195117.34 & 500456.55 & 195117.31 & 500456.72 & 195117.34 \\
\hline 24 & 500458.43 & 195118.10 & 500458.41 & 195118.19 & 500458.43 & 195118.10 \\
\hline $25 / 2$ & 500459.09 & 195118.30 & 500459.18 & 195118.33 & 500459.09 & 195118.30 \\
\hline $25 / 1$ & 500459.63 & 195118.58 & 500459.33 & 195118.11 & 500459.38 & 195118.26 \\
\hline 19 & 500500.35 & 195119.16 & 500500.58 & 195119.34 & 500500.48 & 195119.22 \\
\hline $18 / 1$ & 500501.38 & 195120.67 & 500501.30 & 195120.47 & 500501.35 & 195120.51 \\
\hline 30 & 500500.22 & 195121.21 & 500500.18 & 195121.11 & 500500.20 & 195121.15 \\
\hline 31 & 500501.11 & 195121.69 & 500501.44 & 195121.85 & 500501.40 & 195121.79 \\
\hline 33 & 500501.07 & 195122.17 & 500501.16 & 195122.11 & 500501.20 & 195122.14 \\
\hline 32 & 500501.11 & 195122.65 & 500501.27 & 195122.87 & 500501.20 & 195122.85 \\
\hline $34 / 2$ & 500500.59 & 195122.86 & 500500.49 & 195122.82 & 500500.50 & 195122.86 \\
\hline 347 & 500457.37 & 195122.24 & 500457.30 & 195122.23 & 500457.33 & 195122.24 \\
\hline $28 / 1$ & 500457.10 & 195118.30 & 500457.11 & 195118.31 & 500457.12 & 195118.30 \\
\hline $28 / 2$ & 500456.69 & 195118.85 & 500456.59 & 195118.84 & 500456.65 & 195118.85 \\
\hline 29 & 500457.03 & 195119.77 & 500457.13 & 195119.76 & 500457.11 & 195119.77 \\
\hline 45 & 500459.12 & 195126.01 & 500459.17 & 195126.03 & 500459.14 & 195126.01 \\
\hline 46 & 500456.00 & 195124.43 & 500456.11 & 195124.45 & 500456.12 & 195124.43 \\
\hline 47 & 500457.44 & 195125.98 & 500457.48 & 195125.94 & 500457.46 & 195125.98 \\
\hline 48 & 500457.10 & 195126.28 & 500457.12 & 195126.28 & 500457.11 & 195126.28 \\
\hline 49 & 500457.41 & 195126.94 & 500457.44 & 195126.96 & 500457.43 & 195126.94 \\
\hline 50 & 500457.24 & 195127.58 & 500457.18 & 195127.56 & 500457.20 & 195127.58 \\
\hline $51 / 1$ & 500459.91 & 195129.20 & 500459.89 & 195129.21 & 500459.90 & 195129.20 \\
\hline $51 / 2$ & 500456.65 & 195127.59 & 500456.70 & 195127.56 & 500456.68 & 195127.59 \\
\hline $52 / 1$ & 500458.61 & 195128.96 & 500458.63 & 195128.99 & 500458.62 & 195128.96 \\
\hline $52 / 2$ & 500455.90 & 195127.59 & 500455.89 & 195127.57 & 500455.91 & 195127.59 \\
\hline $52 / 3$ & 500454.32 & 195126.83 & 500454.28 & 195126.81 & 500454.29 & 195126.83 \\
\hline 53 & 500456.82 & 195128.61 & 500456.85 & 195128.61 & 500456.84 & 195128.61 \\
\hline 54 & 500457.00 & 195129.27 & 500457.11 & 195129.25 & 500457.12 & 195129.27 \\
\hline 55 & 500457.03 & 195129.81 & 500457.13 & 195129.81 & 500457.10 & 195129.81 \\
\hline 56 & 500456.89 & 195130.33 & 500456.88 & 195130.32 & 500456.87 & 195130.33 \\
\hline 57 & 500457.10 & 195130.70 & 500457.13 & 195130.73 & 500457.12 & 195130.70 \\
\hline 58 & 500453.64 & 195129.03 & 500453.69 & 195129.05 & 500453.69 & 195129.03 \\
\hline 59 & 500453.77 & 195129.68 & 500453.81 & 195129.61 & 500453.79 & 195129.68 \\
\hline 60 & 500456.34 & 195130.94 & 500456.40 & 195130.95 & 500456.39 & 195130.94 \\
\hline 61 & 500456.28 & 195131.36 & 500456.32 & 195131.37 & 500456.31 & 195131.36 \\
\hline $62 / 1$ & 500453.50 & 195130.50 & 500453.56 & 195130.53 & 500453.55 & 195130.50 \\
\hline 64 & 500457.13 & 195132.11 & 500457.12 & 195132.13 & 500457.14 & 195132.11 \\
\hline 65 & 500457.06 & 195133.00 & 500457.09 & 195133.02 & 500457.07 & 195133.00 \\
\hline 68 & 500457.20 & 195133.96 & 500457.44 & 195133.93 & 500457.34 & 195133.93 \\
\hline 69 & 500457.68 & 195137.01 & 500457.83 & 195137.02 & 500457.80 & 195137.04 \\
\hline 331 & 500453.60 & 195127.24 & 500453.62 & 195127.21 & 500453.61 & 195127.23 \\
\hline 338 & 500454.60 & 195121.97 & 500454.63 & 195121.92 & 500454.62 & 195121.95 \\
\hline $15 / 2$ & 500456.65 & 195112.85 & 500456.61 & 195112.83 & 500456.62 & 195112.82 \\
\hline 333 & 500502.82 & 195105.01 & 500502.81 & 195105.02 & 500502.81 & 195105.03 \\
\hline
\end{tabular}


Table 2. Differences of location coordinates of plots on the basis of data from the Geoportal and two-folded measurements GPSmap62st and GPSmap62st expressed in metric measure after the transformation into the geodetic system 1992

\begin{tabular}{|c|c|c|c|c|c|c|}
\hline \multirow[t]{2}{*}{ Number of plot } & \multicolumn{2}{|c|}{$\begin{array}{l}\text { GEOPORTAL/ } \\
\text { GPSmap62st(1) }\end{array}$} & \multicolumn{2}{|c|}{$\begin{array}{l}\text { GEOPORTAL/ } \\
\text { GPSmap62st(2) }\end{array}$} & \multicolumn{2}{|c|}{$\begin{array}{l}\text { GPSmap62st(1)/ } \\
\text { GPSmap62st(2) }\end{array}$} \\
\hline & $X[\mathrm{~m}]$ & $Y[\mathrm{~m}]$ & $X[\mathrm{~m}]$ & $Y[\mathrm{~m}]$ & $X[\mathrm{~m}]$ & $Y[\mathrm{~m}]$ \\
\hline $15 / 1$ & 2.5 & 3.5 & 0.0 & 0.0 & -2.5 & -3.5 \\
\hline 16 & 1.2 & 1.0 & 0.9 & 0.6 & -0.3 & -0.4 \\
\hline 17 & 2.5 & 0.2 & 0.0 & 0.0 & -2.5 & -0.2 \\
\hline 334 & 11.4 & -2.5 & 0.0 & 0.0 & -11.4 & 2.5 \\
\hline 20 & 2.5 & 5.3 & 1.0 & 3.2 & -1.6 & -2.2 \\
\hline 21 & -7.1 & -2.7 & -4.0 & $\begin{array}{l}-1.1 \\
\end{array}$ & 3.1 & 1.6 \\
\hline 22 & -5.2 & 3.4 & 0.0 & 0.0 & 5.2 & -3.4 \\
\hline 23 & 7.4 & 0.7 & 0.0 & 0.0 & -7.4 & -0.7 \\
\hline 24 & 9.9 & 0.3 & 0.0 & 0.0 & -9.9 & -0.3 \\
\hline $25 / 2$ & 5.3 & 0.7 & 0.0 & 0.0 & -5.3 & -0.7 \\
\hline $25 / 1$ & 0.6 & 0.0 & 0.0 & 0.0 & -0.6 & 0.0 \\
\hline 19 & 9.4 & 9.4 & 7.8 & 6.3 & -1.6 & -3.2 \\
\hline $18 / 1$ & -2.8 & 0.0 & 0.0 & 0.0 & 2.8 & 0.0 \\
\hline 30 & -0.3 & 0.0 & -0.6 & 0.0 & -0.3 & 0.0 \\
\hline 31 & 3.1 & 1.0 & 1.2 & 0.0 & -1.9 & -1.0 \\
\hline 33 & -3.1 & 1.4 & -2.5 & 0.0 & 0.6 & -1.4 \\
\hline 32 & 1.3 & 2.2 & 0.6 & 1.2 & -0.6 & $\begin{array}{l}-1.0 \\
\end{array}$ \\
\hline $34 / 2$ & -10.2 & -2.1 & -9.0 & -1.9 & 1.2 & 0.2 \\
\hline 347 & -5.0 & -2.9 & -2.8 & -3.9 & 2.1 & -1.0 \\
\hline $28 / 1$ & -2.8 & 1.4 & -4.0 & 0.6 & -1.2 & -0.8 \\
\hline $28 / 2$ & -0.6 & 0.8 & -0.3 & 0.2 & 0.3 & -0.6 \\
\hline 29 & 0.3 & 0.2 & 0.3 & -0.4 & 0.0 & -0.6 \\
\hline 45 & 0.0 & 0.0 & 0.0 & 0.0 & 0.0 & 0.0 \\
\hline 46 & -0.9 & 1.4 & -0.6 & 0.4 & 0.3 & -1.0 \\
\hline 47 & 3.1 & 1.2 & 2.8 & 0.0 & -0.3 & -1.2 \\
\hline 48 & 2.2 & 0.8 & 1.2 & 0.0 & -0.9 & -0.8 \\
\hline 49 & -1.5 & 0.2 & -0.6 & 0.0 & 0.9 & -0.2 \\
\hline 50 & -3.4 & 0.6 & -3.7 & 0.0 & -0.3 & -0.6 \\
\hline $51 / 1$ & -1.2 & 1.6 & -0.6 & 0.0 & 0.6 & -1.6 \\
\hline $51 / 2$ & -0.6 & 1.6 & -0.3 & 0.0 & 0.3 & -1.6 \\
\hline $52 / 1$ & -0.9 & 0.8 & -0.6 & 0.0 & 0.3 & -0.8 \\
\hline $52 / 2$ & 1.9 & 1.6 & 1.2 & 0.0 & -0.6 & -1.6 \\
\hline $52 / 3$ & 0.6 & 0.0 & 0.3 & 0.0 & -0.3 & 0.0 \\
\hline 53 & -1.5 & 1.8 & -0.9 & 0.0 & 0.6 & -1.8 \\
\hline 54 & -0.6 & 1.2 & -0.3 & 0.0 & 0.3 & -1.2 \\
\hline 55 & 0.3 & 1.8 & -0.3 & 0.0 & -0.6 & -1.8 \\
\hline 56 & 1.2 & 0.6 & 0.9 & 0.0 & -0.3 & -0.6 \\
\hline 57 & -0.9 & 0.2 & -0.6 & 0.0 & 0.3 & -0.2 \\
\hline 58 & -3.4 & 1.4 & -3.7 & 0.0 & -0.3 & -1.4 \\
\hline 59 & -3.1 & 0.2 & -2.2 & 0.0 & 0.9 & -0.2 \\
\hline 60 & 0.3 & 0.6 & 0.6 & 0.0 & 0.3 & -0.6 \\
\hline 61 & -0.9 & 0.0 & -0.6 & 0.0 & 0.3 & 0.0 \\
\hline $62 / 1$ & -1.5 & 0.6 & -1.5 & 0.0 & 0.0 & -0.6 \\
\hline 64 & -1.2 & 1.6 & -0.6 & 0.0 & 0.6 & -1.6 \\
\hline 65 & -1.8 & 0.8 & -1.5 & 0.0 & 0.3 & -0.8 \\
\hline 68 & -1.2 & 1.2 & -0.9 & 0.0 & 0.3 & -1.2 \\
\hline 69 & -1.9 & 0.0 & $\begin{array}{l}-1.5 \\
\end{array}$ & 0.0 & 0.3 & 0.0 \\
\hline 331 & 0.3 & 0.2 & -0.3 & 0.0 & -0.6 & -0.2 \\
\hline 338 & -0.9 & 0.0 & -0.3 & 0.0 & 0.6 & 0.0 \\
\hline $15 / 2$ & -7.4 & 1.3 & -4.3 & 0.6 & 3.1 & -0.6 \\
\hline 333 & -4.6 & 0.3 & -3.7 & -0.6 & 0.9 & -0.8 \\
\hline
\end{tabular}


The methodology shown on the example of the present study can be useful especially in relation to agricultural and forestry plots, for which the principal identifier is a number, rather than address. The advantage of the used methodology is a low cost of the receiver and relatively high accuracy of the obtained results of positioning. The present research has shown that it can be used in the work requiring the lowest geodetic accuracy for example finding the cadastral plot in the area for the purposes of valuation (when only the parcel number is known). It can be particularly useful when the appraiser has an assignment of valuation of a plot (in the agriculture or forestry area), and the unambiguous position of this plot does not result from the cadastral map. After the number of the plot its approximate coordinates from Geoportal may be determined and then navigate to the specified point (for example using a receiver GPSmap62st).

The biggest problem with navigation to the point was the lack of direct access to some of the plots and the need to seek other ROUTES to achieve the TARGET. This problem can be minimized by setting the operation mode of GPSmap62st to the pedestrian navigation and updating maps preloaded on a receiver.

On the basis of the research it has been shown, that GPSmap62st receivers can be used to find the cadastral plot in the agricultural area, to identify the object of valuation. They are helpful, especially when the cadastral plots in the immediate vicinity of valuation object do not have any specific elements of the management or landscape, so that the appraiser could easily and unambiguously identify the object of valuation in the field. The possibility of using this instrument significantly reduces the operating time of the surveyor and ensures proper selection of the valuation object in the field.

During the analysis of the research topic one more conclusion arrived, not related directly to the topic, but important due to the general topic of researches undertaken by the authors. So, it should be noted that if in the Polish real estate cadastre (now EGiB) were located complete data related to the configuration of the borders of plots and clearly defined borders breakpoints - plot search methodology using GPSmap62st (or any other handheld GPS receiver of this class of precision) would consist in the navigation by co-ordinates entered in the Real Estate Cadastre. At this point, one should mention that the receiver after suitable setup can work also in the geodetic co-ordinates mode, for example in 2000 or 1965 system.

\section{References}

[1] Gajewski J. (red.): Nawigacja dla żeglarzy. Almapress, Warszawa 2007.

[2] Grubbs B.: GPS. Poradnik użytkownika. Wydawnictwo RM, Warszawa 2009.

[3] Höh R.: Kompas i GPS dla początkujacych. Wydawnictwo Bezdroża, Kraków 2005.

[4] Jacobson C.: Mapa, kompas, GPS. Wydawnictwo Eremis, Warszawa 2007. 
[5] Kwinta A., Szeptalin A.: Wykorzystanie ręcznych odbiorników GNSS do pomiarów powierzchni działek rolnych. Infrastruktura i Ekologia Terenów Wiejskich, nr 6, 2010, pp. 157-166.

[6] Lamparski J., Światek K.: GPS w praktyce geodezyjnej. Wydawnictwo GALL, Katowice 2007.

[7] Mika M.: Wykorzystanie ręcznych odbiorników GPS w Systemie Jednolitej Płatności Obszarowej dla wyznaczenia pól powierzchni działek. Infrastruktura i Ekologia Terenów Wiejskich, nr 3, 2011, pp. 53-62.

[8] Mika M.: Examination of the Capabilities of Some Models of Hand GPS Receivers for Purposes of Creation of Thematic Maps. Geomatics and Environmental Engineering, vol. 8, no. 2, 2014, pp. 47-56.

[9] Narkiewicz J.: GPS i inne systemy nawigacyjne. Wydawnictwa Komunikacji i Łączności, Warszawa 2007.

[10] Plewako M.: Badanie dokładności ręcznych odbiorników GPS. Infrastruktura i Ekologia Terenów Wiejskich, nr 12, 2010, pp. 103-107.

[11] Siejka M.: Wstępne wyniki eksperymentów z wykorzystaniem systemu EGNOS, wykonanych za pomoca odbiornika Garmin GPSmap 76CSx. Zeszyty Naukowe Akademii Rolniczej im. Hugona Kołłątaja w Krakowie, nr 431, Geodezja, z. 22, 2006, pp. 177-184.

[12] Siejka Z.: Analiza aktualnych dokładności i precyzji ręcznego odbiornika GPS z sygnałem EGNOS. Infrastruktura i Ekologia Terenów Wiejskich, nr 1/II, 2012, pp. 121-128.

[13] Szostak M., Wężyk P.: Pomiary GNSS w przestrzeni leśnej przy wykorzystaniu różnej klasy odbiorników oraz wybranych technik pomiaru. Archiwum Fotogrametrii, Kartografii i Teledetekcji, vol. 25, 2013, pp. 217-231.

[14] www.geocaching.pl/.

[15] www.geoportal.gov.pl. 